\title{
GREEN INNOVATIONS IN REGIONAL ECONOMY
}

\author{
Tatjana Tambovceva ${ }^{1}$, Maria Tereshina ${ }^{2}$, Vera Samarina ${ }^{3}$ \\ ${ }^{1}$ Riga Technical University, Latvia; ${ }^{2}$ Kuban State University, Russia; ${ }^{3}$ Staryy Oskol Technological \\ Institute, branch of National Research Technological University "MISIS", Russia \\ tatjana.tambovceva@rtu.lv, mwstepanova@mail.ru, samarina_vp@mail.ru
}

\begin{abstract}
Nowadays, the concept of innovation is a generally accepted approach to promoting sustainable development. However, the continuing deterioration of the environment, the rapid changes in external conditions in relation to science and innovation, and the need for regions to switch to a green economy, determine the need for scientific search in the field of "correct" innovations, organically integrating social, economic and environmental imperatives. This kind of innovation is known as green innovation. Innovation and entrepreneurship are needed to utilize new technologies towards a sustainable society. Eco-innovation and green technologies play an essential role for: greener economic and social development, economic growth, improved productivity and competitiveness, and improved quality of life. The purpose of the article is to describe the regional context of the promotion of "green" innovations and an analysis of the main trends and factors influencing this process. The authors used the analysis of statistical and analytical data, a comparative analysis of the experience of different countries, considered the types of "green" innovations, their dynamics and factors of development. A structural model of a regional eco-innovation system is proposed. The research highlights the special status of green innovations in regional development, based on their specific characteristics, such as the ability to create public environmental benefits, manifestation of positive external effects, including network effects, the ability to convert environmental and economic benefits into significant social effects, hybrid and multiplicative. Ecological innovations, developing in a quantitative and qualitative format, can become a backbone component of a regional innovation system and at the same time a source of technological, structural, and institutional changes during the transition to sustainable regional development.
\end{abstract}

Keywords: green innovations, eco-innovations, green economy, regional economy, sustainable development

\section{Introduction}

A number of circumstances determine the relevance of the problems stated in the article. Nowadays, the concept of innovation is a generally accepted approach to promoting sustainable development [1]. However, the continuing deterioration of the environment, the rapid changes in external conditions in relation to science and innovation, and the need for regions to switch to a green economy, determine the need for scientific search in the field of "correct" innovations, organically integrating social, economic and environmental imperatives. This kind of innovation is known as green innovation.

Despite the fact that there is no universally accepted definition of "green" innovation, a basic definition can be taken from the Action Plan of the European Commission on Eco-Innovation. It defines eco-innovation as, "Eco-innovation is the introduction of any new or significantly improved product (goods or service), process, organisational change or marketing solution that reduces the use of natural resources (including materials, energy, water and land) and decreases the release of harmful substances across the whole life-cycle." [2].

A significant increase in the research in green innovation dates back to 2009, although the first publications appeared around 2000 [3]. Reflection of the changing social, ecological and economic reality of innovative systems in the literature finds its definition in the specification of the concept of ecological or green innovation [4-6]; classification and typology of eco-innovation [7-9]; ecoinnovation policy and management [10-13], as well as methods for their measurement [14-15].Green innovation can save resources and reduce environmental pollution by improving production efficiency, saving energy, and reducing emissions [16].

\section{Materials and methods}

The methodological basis of this study was an interdisciplinary approach, including a comparative analysis of scientific discourse on green innovation, as well as an analysis of reports and studies on various aspects of the development of the green economy and green innovation, case analysis, and statistical data analysis. System analysis was based on a quantitative approach. 
The purpose of the article is to describe the regional context of the promotion of "green" innovations and an analysis of the main trends and factors influencing this process.

\section{Results and discussion}

\section{Green innovation and sustainable regional development}

Creating a technology is not enough to reach a sustainable society. Innovation and entrepreneurship are needed to utilize new technologies towards a sustainable society. As mentioned above, a variety of theoretical and applied approaches to the study of green or environmental innovations determine the many existing classifications that are allocated, mainly in accordance with the ultimate goals of the study.The classification of "green" innovations, affiliated with the sustainable development goals (SDG), is proposed by Park et.al.[17].

Nine sectors of the green economy, which also correspond to the SDGs, are considered as the most relevant areas of innovation activity, (Fig. 1).

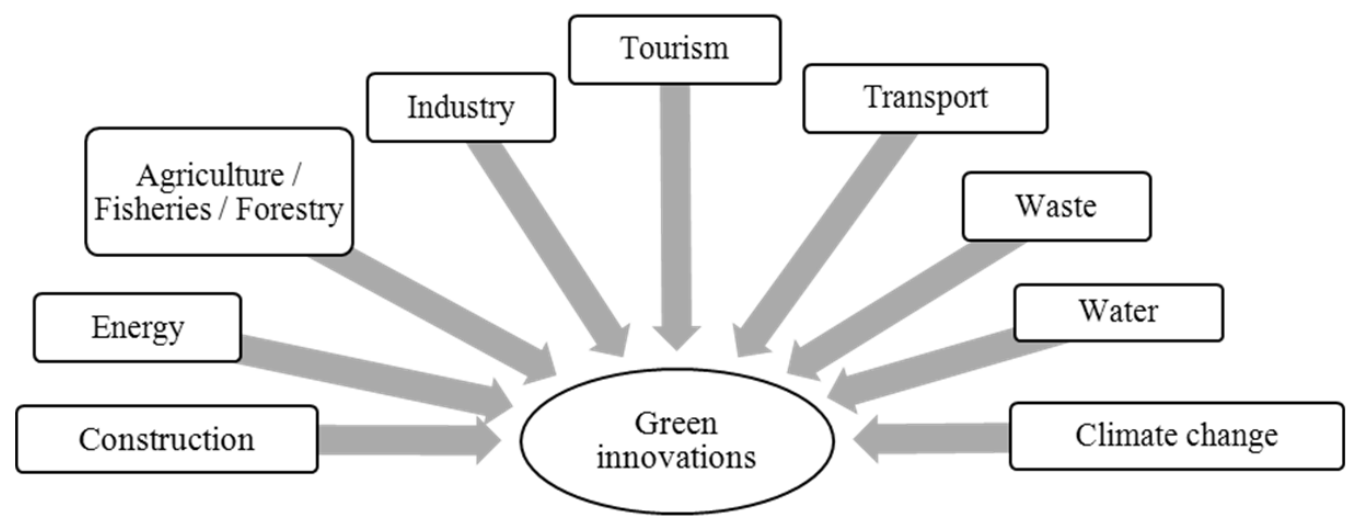

Fig. 1. Directions for green innovation according to sustainable development goals [16]

It should be noted that in the framework of the Agenda 2030,alsocalled the Technology Facilitation Mechanism (TFM) was created to identify the main innovations in the field of sustainable development. Comparison of the SDGs and the existing opportunities to achieve them allowed them to be classified into four types: sectoral, inter-sectoral, global and universal cross-cutting [18].

Arundel and Kemp [15] in their studies provide an extended classification of eco-innovations, highlighting the technologies aimed at protecting the environment; organizational innovations for the environment, innovative products and services, the use of which benefits the environment and ecosystem innovations. In accordance with the proposed classification, the content of green innovations can be represented as follows (Table 1).

Table 1

Types and content of "green" innovation

\begin{tabular}{|c|l|}
\hline Types of innovations & \multicolumn{1}{c|}{ Content } \\
\hline $\begin{array}{c}\text { Environment protection } \\
\text { technologies }\end{array}$ & $\begin{array}{l}\text { Pollution control technologies and contributing to the reduction of } \\
\text { environmental pollution, rationalization of the use of production } \\
\text { resources; technology development and equipment manufacturing, } \\
\text { optimizing the process of waste disposal; technologies and tools for } \\
\text { environmental monitoring, energy conservation, noise control, etc. }\end{array}$ \\
\hline $\begin{array}{c}\text { Organizational } \\
\text { innovations for the } \\
\text { environment }\end{array}$ & $\begin{array}{l}\text { Environmental audit, environmental controlling, environmental } \\
\text { management systems, greening supply chains throughout the product } \\
\text { life cycle }\end{array}$ \\
\hline $\begin{array}{c}\text { Innovative products and } \\
\text { services that benefit the } \\
\text { environment }\end{array}$ & $\begin{array}{l}\text { New or environmentally improved products, "green" financial } \\
\text { products, environmental consulting, testing and design, services to } \\
\text { reduce environmental pollution and optimal use of resources }\end{array}$ \\
\hline $\begin{array}{c}\text { Ecosystem innovations } \\
\text { Alternative production methods and consumer behaviour patterns, } \\
\text { organic agriculture and renewable energy }\end{array}$ \\
\hline
\end{tabular}


In general, there is no universal toolkit that enables the exploration of innovative processes with an environmental effect within various regional systems. This is why the most important issue is the integration of a theoretical approach to the research methods of "green" innovation and practical tools for measuring innovation at the level of organizations, territorial entities and other economic systems.

\section{Effects of green innovation in a regional context.}

For successful implementation of the "green" economy potential in the development of rural areasthe following conditions are necessary: focus on the existing demand in the sphere of market or social problems, balance of environmental, social and economic goals, their clarity and economic validity, innovation, availability of sustainable network communications and transparent intersectoral interaction, diversification of funding sources, adaptability to changes in the external conditions, availability of educational programs, monitoring of planned and actual indicators, broadcasting of successful experience and results, formation of socio-ecological identity and a new ecological mentality, norms and the level of trust between members of the local community as well as information support [19].

The effect of "green" innovation is that it contributes to "green" growth, both through technological and non-technological changes. The conventional typology of ecological innovations proposed by the OECD [20] provides an opportunity to evaluate the potential effect of green innovations for the regional economy and society.

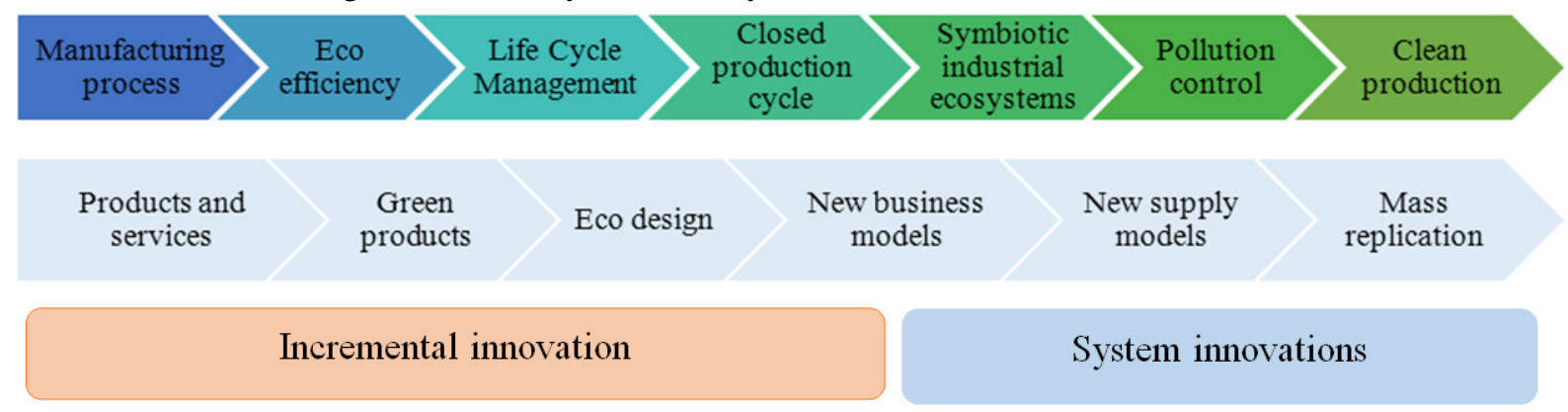

Fig. 2. Structure and effects of incremental and systemic eco-innovations

Incremental (gradual) innovations are aimed at changing and improving existing technologies, increasing the efficiency of resource use and energy without fundamentally changing the technological basis of production. Their effect is in relative decoupling (gradual reduction in the use of resources per unit of added value). Nowadays, it is the dominant form of eco-innovation in enterprises.

Systemic (radical) innovations imply full-scale structural and technological changes in economic systems, achieving the effect of absolute decoupling (sustainable or declining use of resources and environmental impacts while the economy is growing). Systemic eco-innovations can be simple, but with a very wide range of applications, or rather complex ones that form whole networks of actors and transformation complexes in organizational and institutional mechanisms.

The overall differences between incremental and systemic innovations are shown in Figure 2. It seems that, despite the greater potential of systemic eco-innovations, incremental innovations are extremely important, because they capture successful social practices and contribute to the diffusion of innovations in the regional space.

The priority for "green growth" is the support of innovations that can create prospects for new economic opportunities [21]. Therefore, the concept of "ecological modernization of the regional economy" should include not only technological innovations, but also modernization of institutes and legal regulators of spatial development, ensuring "greater compliance of these institutions and regulators with the scale and complexity of the subject of this management" [22].

Among the specific effects of "green" innovations that determine their special status in the regional innovation system are the following:

- ability to create public environmental benefits;

- manifestation of positive external effects, including network effects, reflecting the growing value of innovations due to the expansion of the number of consumers; 
- ability to convert environmental and economic benefits into significant social effects;

- having a hybrid and multiplicative nature, which is supported by the fact that most environmental innovations have, firstly, associated technological solutions, and secondly, create incentives for innovation processes (technological, product, service, organizational, marketing, institutional and social) in other industries, and the system as a whole.

From a regional development perspective, the existing strategic approaches almost do not take into account the eco-innovation component as a competitive advantage, the basis of which can form a development strategy. At the same time, the support and development of environmental technologies can become the basis of a region's development strategy, helping to increase its competitiveness and investment attractiveness.

\section{“Green” design of regional innovation systems.}

The process of transition to a post-industrial society not only changes the economy, but also its interrelations with other sources of social and political development. It gives rise to a request for increasing the reliability of innovation and science and technology policies, and the search for new ways to manage innovations. Nowadays, ideas about new models of the innovation system are developed, new approaches to explaining the processes of generation, diffusion and acceleration of innovations are being formed, corresponding to the current stage of development. Research has long recognized the importance of innovation systems, rather than focusing on individual events. Figure 3 shows the regional eco-innovation model with the main determinants and structural factors of development.

According to this approach, in order to determine the ways of management impact aimed at developing the constructive potential of a regional eco-innovation system and neutralizing environmental risks and threats, it is necessary to create a system of indicators "tied" to the conditions of a specific region and based on a multi-dimensional scale of quantitative and qualitative indicators. Monitoring these indicators would allow potential diffusion of eco-innovative practices to be analysed and predicted. Eco-innovative practices depend on the degree of development of various elements of a regional innovation system because of evolutionary changes in the interface and architecture of the institutions that comprise it; they take into account the nature of the interconnections and interactions between them and the factors determining their configuration and dynamics. At the same time, such a system should be a compromise between the need for maximum representation and a rather limited set of its constituent indicators.

The main advantages of creating and implementing such a system can be:

- forecasting the activities of organizations in the field of eco-innovation and consumer behaviour;

- identifying incentives and barriers to creating, implementing, transposing and replicating of "green" innovations in order to develop an effective regional socio-economic and environmental policy;

- raising awareness of environmental innovations among various groups of stakeholders;

- creating a need for ecological products and an ecological lifestyle.

\section{Factors affecting the development of environmental innovation at the regional level}

The existing theoretical approaches focus on various factors that determine the development of environmental innovation.

J. Medeiros identifies four main factors for the success of an environmentally-oriented innovation product [23]: market, legislation and regulation, inter-sectoral interaction, training, and research and development in the field of eco-innovation. Moreover, all factors are strongly interconnected.

The "turtle" model proposed by Fichter [24] combines internal (created by participants of the value chain) and external (not directly related to the value chain) driving forces of eco-innovation. The author uses a multi-impulse approach, considering the actors of eco-innovation at various levels. This modelis based on the "push-pull" approach and pays considerable attention to the institutional aspects 
of promoting eco-innovation. Many theoretical models proposed by foreign researchers require adaptation to the particular regional practice.

Undoubtedly, the development of environmental innovations is a complex process with many components, but in this research the authors focus on the problem of creating demand for environmental innovations and their institutional support through the instruments of public policy.

Demand for eco-innovation can be both from consumers (consumer demand) and business (investment demand). In fact, although both of these types of demand are different in nature, they are nevertheless closely interconnected.

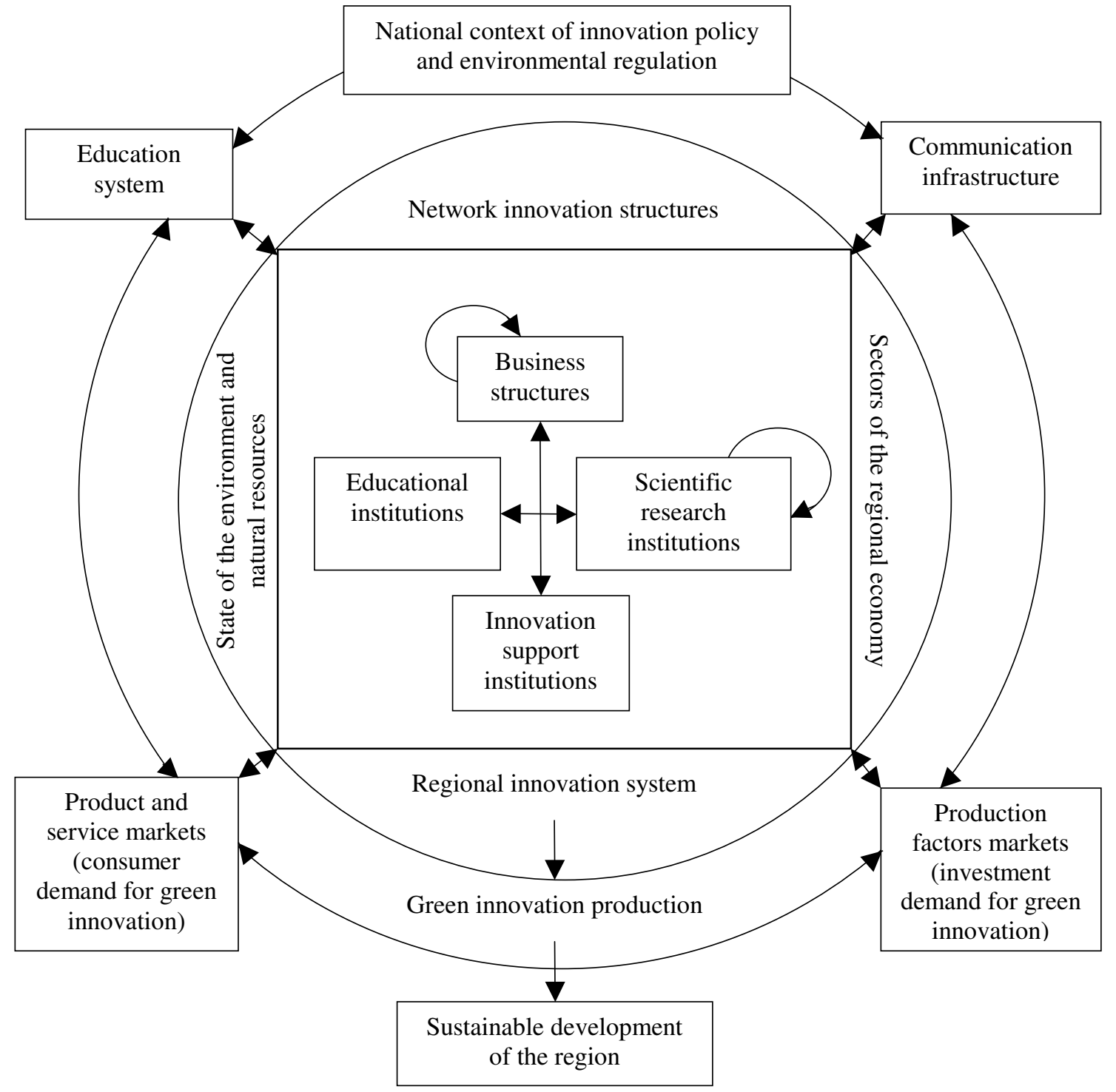

Fig. 3. Actors and connections in regional eco-innovation systems

Regional aspects in shaping eco-innovation demand are extremely important, since regional specificity determines both the social demand for ecological farming and the market demand for certain types of environmental goods and services in accordance with the local characteristics.

Eco-oriented innovative behaviour of consumers appears under the influence of two groups of factors. The social effect based on ideas about the need for a healthy and eco-friendly lifestyle, integrating the need to protect and preserve the natural environment into the system of consumer values; as well as environmental marketing technologies, including adherence to environmental standards, and is due to the preference for "new" products or services with a minimal impact on environment. At the same time, an increase of the income level and quality of life creates additional 
conditions for a social effect, since innovative "green" goods or services are regarded as being among the normal or highest goods.

The speculative effect is associated with consumer expectations and occurs, when awareness of the threat of failing health or potential financial losses stimulates the consumption of innovative green goods and services to meet basic security needs. The use of direct and indirect methods of regulation used by the state (for example, various kinds of preferences to producers and consumers) can significantly enhance this effect.

The effect of consumers' limited rationality, due to the high transaction costs of finding information about innovative eco-oriented goods and services, as well as the prevailing sustainable management stereotypes and lack of interest in innovations, can be overcome by developing environmental certification and standardization, environmental auditing, and controlling.

Investment demand for environmentally-oriented technological innovations is formed mainly in the framework of government incentives for environmental modernization of industry and reducing the energy intensity of products. In the modern economy, a set of innovative policy measures and instruments that support investment demand for green innovations can include a wide range of components: green government procurement, systems for environmental standards, special institution of leading markets (used in the EU to support the formation of renewable energy markets), encouraging the creation of various partnerships.

\section{Conclusions}

1. The data of indicators, characterizing the quantitative slice of the level of eco-innovation development at the regional level demonstrates that "green" innovative practices do not currently receive mass distribution and replication. The results of the study highlight the special status of "green" innovations in regional development, based on their specific characteristics, such as the ability to create public environmental benefits, demonstration of positive external effects, including network effects, ability to convert environmental and economic benefits into significant social effects, and the hybrid and multiplicative character of "green" innovations. Ecological innovations, developing in a quantitative and qualitative format, can become a backbone component of a regional innovation system and at the same time a source of technological, structural and institutional changes during the transition to sustainable regional development.

2. The lack of representative statistical data to determine the methods of management impact aimed at developing the constructive potential of a regional eco-innovation system requires the creation of a system of indicators "tied" to the conditions of a particular region and based on a multidimensional scale of quantitative and qualitative features. They should take into account the degree of development of various elements of regional innovation systems influenced by changes in the interface and architecture of its constituent institutions.

3. An analysis of measures implemented in different countries to support investment demand for environmental innovations shows the focus of efforts of regulators in this direction in recent years, especially regarding regulatory and legal regulation. However, in general, institutional support for shaping and stimulating the demand for green innovation has not become a significant component of innovation policy, which is one of the reasons for the lack of effectiveness of measures in this area.

\section{Acknowledgements}

The research wascarried out with the support of the RFBR project No. 18-410-230028 "Institutional design of Krasnodar Region's innovation system: capacity development, neutralization of risks and threats".

\section{References}

[1] Доклад о человеческом развитии в Российской Федерации за 2018 год. / под ред. С.Н. Бобылева, Л.М. Григорьева. (Human Development Report in the Russian Federation for 2018. Manandinnovations. (2018). Ed.ByBobilev S.N., Grigorjev L.M. ). М.: Аналитический центр при Правительстве Российской Федерации, 2018: Analytical Center for the Government of the 
Russian Federation, 2018. (InRussian). [online] [3.02.2019]. Available at: http://ac.gov.ru/files/publication/a/19663.pdf

[2] Eco-innovation observatory methodological report August 2012. [online] [3.02.2019]. Available at: http://www.eco-innovation.eu/index.php/reports/methodological-report

[3] Jo J.H., Roh T.W., Kim S., Youn Y.C., Park M.S., Han K.J., Jang E.K. Eco-innovation for sustainability: evidence from 49 countries in Asia and Europe. Sustainability, vol. 7, 2015, pp. 16820-16835.

[4] Rennings K. Redefining innovation. Eco-innovation research and the contribution from ecological economics. Ecological Economics, vol.32, 2000, pp. 319-332.

[5] Karakaya E., Hidalgo A., Nuur C. Diffusion of eco-innovations: a review. Renewable \& sustainable energy reviews, vol. 33, no May, pp. 392-399.

[6] Hellström T. Dimensions of environmentally sustainable innovation: the structure of ecoinnovation concepts. Sustainable Development, vol.15, 2007, pp. 148-159.

[7] OECD. Eurostat. Oslo Manual: Guidelines for Collecting and Interpreting Innovation Data. 3rd ed. Paris: OECD, 2005.

[8] EIO. Methodological Report; Eco-Innovation Observatory, 2012. [online] [4.02.2019]. Available at: http://www.un-documents.net/wced-ocf.htm

[9] Horbach J., Rammer C., Rennings K. Determinants of eco-innovations by type of environmental impact - the role of regulatory push/pull, technology push and market pull. Ecological Economics, vol.78, 2012, pp. 112-122.

[10] Jang E.K., Park M.S., Roh T.W., Han K.J. Policy instruments for eco-innovation in Asian countries. Sustainability, vol.7, 2015, pp. 12586-12614.

[11]Leitner A., Wehrmeyer W. France C. The impact of regulation and policy on radical ecoinnovation: the need for a new understanding. Management Research Review, vol.33, 2010, pp. 1022-1041.

[12] Behnam S., Cagliano R. Be Sustainable to be innovative: an analysis of their mutual reinforcement. Sustainability, vol.9, No.1, 2017, pp. 17.

[13] OECD. The Future of Eco-Innovation: The Role of Business Models in Green Transformation. Paris: OECD, 2012.

[14] Kemp R., Pearson P. Final report MEI project about measuring eco-innovation. Maastricht: UM Merit, 2007.

[15] Arundel A., Kemp R. Measuring eco-innovation. Maastricht: UM Merit, 2009.

[16]Feng Z., Chen W. Environmental Regulation, Green Innovation, and Industrial Green Development: An Empirical Analysis Based on the Spatial Durbin Model. Sustainability, 2018, 10, 223.https://doi.org/10.3390/su10010223

[17] Park M., Bleischwitz R., Han K., Jang E., Joo J. Comparing eco-innovation indices: ASEM ecoinnovation index \& eco-innovation scoreboard. London: ASEIC and University College London, 2016.

[18] Liu W., Kanehira N., Alcorta L. An overview of the UN technology initiatives // United Nations Inter-agency working group on a technology facilitation mechanism. Background Paper No. 2015/1. [online] [3.03.2019]. Available at: https://sustainabledevelopment.un.org/content/documents/7810Mapping \%20UN \%20Technology \%20Facilitation \%20Initiatives \%20July \%2023\%202015\%20clean \%203.pdf

[19] Tambovceva T., Tereshina M. Economic potential of "green" economy in development of rural territories. Proceedings of the 2018 International Conference "Economic science for rural development" No 48 Jelgava, LLU ESAF, 911 May 2018, pp. 259267https://doi.org/10.22616/ESRD.2018.093

[20] OECD. Organisation for economic co-operation and development // Fostering innovation for green growth. OECD publishing, 2011. [online] [3.03.2019]. Available at: http://www.oecd.org/eu/fosteringinnovationforgreengrowth.htm

[21]Бобылев С.Н., Соловьева С.B. (Bobylev S.N., Solov'eva S.V.) Новые цели для новой экономики. (New targets for the new economy). Мирновойэкономики (World of New Economy), No 1, 2016, pp. 6-14. (In Russian). 
[22] Leksin V.N., Porfryev B.N. Modernization of institutional and legal bases for the development of the Russian Arctic // MIR (Modernizatsiia. Innovatsii. Razvitie),vol. 9, No. 3, 2018, pp. 351-363. https://doi.org/10.18184/2079-4665.2018.9.3.351-363

[23] Medeiros J. Success Factors for environmentally sustainable product innovation: a systematic literature review. Journal of Cleaner Production,vol. 65, 2014,pp. 76-86.

[24] Fichter K., Innovation communities: a new concept for new challenges. Innovation Communities,K. FichterandS.Beucker (eds). Springer Verlag, 2012, pp.1-15.

https://doi.org/10.1007/978-3-642-22128-6_1 